\title{
Study on solar absorptance and thermal stability of solid particles materials used as TES at high temperature on different aging stages for CSP applications.
}

\author{
Anabel Palacios ${ }^{1,2}$, Alejandro Calderón ${ }^{1}$, Camila Barreneche ${ }^{1,2}$, Joan Bertomeu ${ }^{3}$, Mercè \\ Segarra $^{1}$, A. Inés Fernández ${ }^{1, *}$ \\ ${ }^{1}$ Departament de Ciència de Materials i Química Física, Universitat de Barcelona, Martí i Franquès 1, \\ 08028 Barcelona, Spain. Tel.: 934021317. ana inesfernandez@ub.edu \\ ${ }^{2}$ Birmingham Centre for Energy Storage \& School of Chemical Engineering, University of Birmingham, \\ Birmingham B15 2TT, United Kingdom \\ ${ }^{3}$ Departament de Física Aplicada, Universitat de Barcelona, Martí i Franquès 1, 08028 Barcelona, Spain
}

\begin{abstract}
The use of solid particles as heat transfer fluid (HTF) presents a great potential to overcome drawbacks addressed in commercial Concentrated Solar Power (CSP) plants. The solid particles thermal energy storage (TES) system allows achieving both high thermal performance at high temperature and low cost from the material perspective. The conversion efficiency of CSP solid particles-based systems at high temperatures strongly depends on the optical properties and thermophysical properties of materials used both as HTF and as storage medium. The present study is aimed to provide more experimental data and evidences of the potential in using particulate solids for CSP application. The solar absorptance and the specific heat capacity of silicon carbide $(\mathrm{SiC})$, silica sand $\left(\mathrm{SiO}_{2}\right)$, and hematite $\left(\mathrm{Fe}_{2} \mathrm{O}_{3}\right)$ are studied after different aging times at $750^{\circ} \mathrm{C}$ and $900^{\circ} \mathrm{C}$. The solar absorptance slightly increases over the aging process except for the silica sand, which decreases its absorptance in the first 100 hours, reaching a plateau. After the aging treatment, the specific heat capacity is increased for both $\mathrm{SiC}$ and silica sand. However, for the iron oxide the specific heat capacity is lower after aging. The black silicon carbide $\mathrm{SiC}$ is proven to be the best option to be used up to $900^{\circ} \mathrm{C}$ as it shows the highest solar absorptance $(96 \%)$ and the highest heat storage capacity.
\end{abstract}

Keywords: solar absorptance; concentrated solar power (CSP); solid particles, thermal energy storage (TES), sensible heat storage 


\section{Introduction}

Lately, renewable energy sources have gained attention due to the depletion of fossil fuels, the increase of greenhouse gas concentration, the climate change and the energetic security for countries with small fossil energies reserves. For these reasons, the European Commission has set up targets to increase the renewable energy supply share in Europe in order to reduce greenhouse gas emissions and mitigate the climate change effects [1]. The highest power density of all renewables by land surface area is offered by direct solar conversion into heat or electricity [2] . Solar energy is one of the most environmentally friendly energy sources [2], and the milestones for solar energy exploit are energy capture, energy conversion, and energy storage. Solar energy can be harnessed generally in two different ways [3]: photovoltaic cells and thermal conversion systems.

In few words, concentrating solar collectors use mirrors and lenses to concentrate and focus sunlight onto a thermal receiver, similar to a boiler tube. The receiver absorbs and converts sunlight into heat. The heat is then transported to a steam generator or engine, where it is converted into electricity or this heat is stored as sensible heat, which can be used once it is required. Concentrated solar power (CSP) using sensible heat system [4] consists on a storage medium (liquid or solid) commonly contained inside a tank.

The CSP technology that has better commercial deployment is the one that uses molten salts as heat transfer fluid (HTF), since it has the advantage of being a relevant energy storage medium [5]. The major drawback of molten salt systems is the allowable operating temperature range, which is limited by the phase change temperature at the low end and the thermal decomposition onset as upper limitation [6]. Therefore, conventional central receiver technologies are limited to temperatures between $220-600^{\circ} \mathrm{C}$.

The use of solid particles as HTF is an option to overcome these drawbacks [7]. The solid particle thermal energy storage (TES) system can achieve both high thermal performance at high temperature and lower cost from the material perspective [8]. Thereby, solid particles fall through a beam of concentrated solar radiation for direct heat absorption and storage. For that reason, direct absorption receivers using solid particles have the potential to increase the maximum temperature of the heat transfer media to more than $1000^{\circ} \mathrm{C}$ [9]. Considering this configuration, CSP systems, from the HTF and TES material viewpoints, are able to operate from $600^{\circ} \mathrm{C}$ to more than $1000^{\circ} \mathrm{C}$. The application of solid particles as storage media is motivated mainly by costefficiency aspects. On the other hand, the material and maintenance costs are expected to be lower for solid particles storage systems [6] as was stated by Calderon et al. [10]. Figure 1 illustrates solid particle CSP plant layout, which includes a solar receiver, high and low temperature storage tanks, a heat exchanger, a conveyance system. In addition, solar field and power block integration with the solid particle system is showed.

Many development efforts are carried out for achieving direct solar solid particle open systems at commercial level. Since efficiency increases with working temperature in CSP systems, finding the optimum properties of solid particle medium at high temperatures is one of the main R\&D challenges in this field. A first attempt to characterize materials for particle receiver applications was conducted by Sandia National Laboratories in the 1980s [11]. Besides, Falcon et al. [12] in 1982 identified silicon carbide, alumina and quartz sand as suitable materials for CSP systems. In the latest years, this topic has kept the researcher's community attention. N. Siegel et al. [13] 
studied the radiative properties, solar weighted absorptance and thermal emittance for several commercially available proppants. The authors concluded that the solar weighted absorptance and thermal emittance of the particles are stable at $700^{\circ} \mathrm{C}$, but not at $1000^{\circ} \mathrm{C}$. From the materials perspective, Baumann et al. [14] studied the grain size, the specific heat capacity, the thermal shock properties, and attrition of different solid particles: silicon carbide, silica sand, alumina, and basalt. This study concluded that none of the materials considered as candidates perfectly fulfills all the requirements. Therefore, compromises and some concessions have to be assigned. In addition, Zhang et al. [15] evaluate some materials to be used in solar tower power plants with the falling particle curtain receiver configuration, concentrating mainly on the fluidized bed recirculation. The materials considered were silica sand, silicon carbide and calcium carbonate. The published studies are focused on the system and solid particles properties in the recirculation and heat exchanger parts of plant $[4,11,16]$. Nevertheless, there is lack of studies including optical properties characterization of the solid particles.

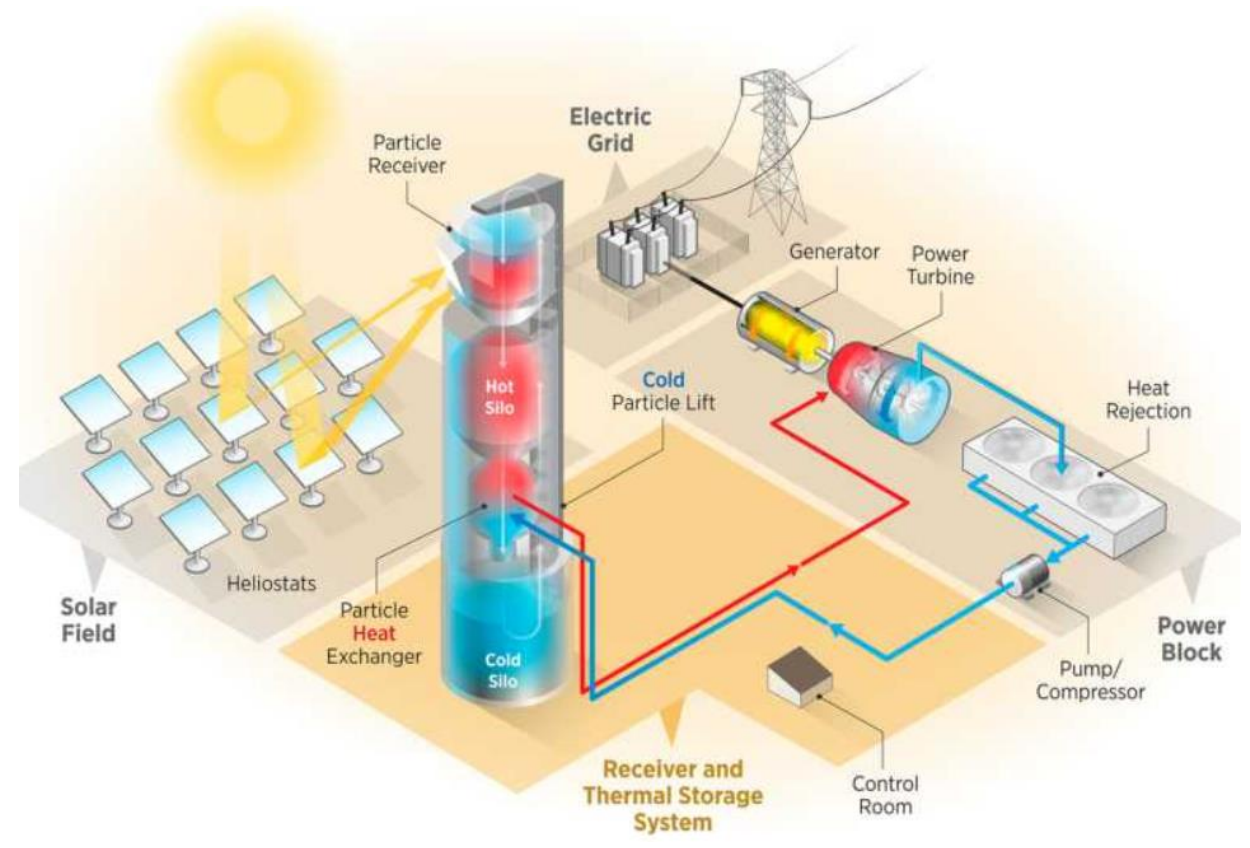

Figure 1 Solid Particle CSP plant layout [17].

The efficiency of CSP system conversion at high temperatures strongly depends on the optical properties and thermophysical properties of materials used as heat transfer fluid and as storage medium. Therefore, the present study is focused on the study and comparison of the solar absorptance and specific heat capacity of solid particle materials as these properties are stated as the most important for a proper material selection for this application [14]. Natural and synthetic materials have been studied and treated with different thermal aging times to simulate material changes due to the high temperature exposure. After the ageing treatment, the materials were characterized to test the optical absorptance, the specific heat, the structural changes and the thermal stability at high temperatures.

\section{Materials}


Since efficiency increases with working temperature in concentrated solar power (CSP) systems, $900{ }^{\circ} \mathrm{C}$ can be easily reached by the CSP receiver and the storage medium. Therefore, the materials used for CSP must fulfill certain requirements restricted by the maximum operation temperature of the application: to withstand high temperatures, thermal shock resistance, high melting temperature, thermal stability and with non-polymorphic changes. The materials source, composition and main advantages and disadvantages to be used as HTF and TES material in CSP systems are listed in Table 1 . Notice that silica sand as curtain receiver configuration TES material has been studied for comparison purposes due to the relevance this material has in the reported literature even though it presents polymorphic changes [12-15].

Notice that two working temperatures were defined in this study. The lower one is $750{ }^{\circ} \mathrm{C}$ since this temperature allows the use of commercially available materials for components, pumps, etc. The upper temperature, $900{ }^{\circ} \mathrm{C}$, has been chosen as the optimal for increasing the efficiency of heat to electricity conversion. 
Table 1. Materials characterized in this study.

\begin{tabular}{|c|c|c|c|c|c|c|}
\hline $\begin{array}{l}\text { Material } \\
\text { name }\end{array}$ & Source & Composition & $\begin{array}{l}\text { Particle size } \\
(\mathbf{m m})\end{array}$ & Advantages & Disadvantages & $\begin{array}{l}\text { Previously } \\
\text { studied }\end{array}$ \\
\hline $\begin{array}{l}\text { Black } \\
\text { silicon } \\
\text { carbide }\end{array}$ & $\begin{array}{l}\text { Synthetic } \\
\text { material } \\
\text { (Panadyne } \\
\text { F150) }\end{array}$ & $\begin{array}{l}\text { Silicon } \\
\text { Carbide } \\
\mathrm{SiC}_{\min } 99.2 \%\end{array}$ & $0.02-0.2$ & $\begin{array}{l}\text { High wear resistance with good mechanical } \\
\text { properties, including high strength at elevate } \\
\text { temperature and thermal shock resistance. High } \\
\text { thermal conductivity. Naturally black color. }\end{array}$ & Cost (synthetic material). & {$[12,14,15]$} \\
\hline $\begin{array}{l}\text { Silica } \\
\text { sand }\end{array}$ & $\begin{array}{l}\text { Mineral } \\
\text { (Sílice de } \\
\text { Segovia SL) }\end{array}$ & $\begin{array}{l}\text { Silicon oxide } \\
\mathrm{SiO}_{2} 95.3 \% \\
\mathrm{Al}_{2} \mathrm{O}_{3} 2.3 \% \\
\mathrm{~K}_{2} \mathrm{O} 1.5 \%\end{array}$ & $0.2-0.5$ & $\begin{array}{l}\text { Very durable mineral, resistant to heat and chemical } \\
\text { attack, high melting point, and non-corrosive. }\end{array}$ & $\begin{array}{l}\text { White color and } \\
\text { polymorphic changes. }\end{array}$ & {$[12-15]$} \\
\hline $\begin{array}{l}\text { Iron } \\
\text { oxide }\end{array}$ & $\begin{array}{l}\text { Mineral } \\
\text { (Óxidos } \\
\text { férricos S.A) }\end{array}$ & $\begin{array}{l}\text { Hematite } \\
\left.\mathrm{Fe}_{2} \mathrm{O}_{3}\right) 95.5 \% \\
\text { Dolomite } \\
1.5 \% \\
\text { Epidote } 1.4 \%\end{array}$ & $<0.15$ & Paramagnetic iron oxide. Naturally black color. & $\begin{array}{l}\text { No notable } \\
\text { disadvantages. }\end{array}$ & {$[13]$} \\
\hline
\end{tabular}




\section{Experimental Methodology}

\subsection{Aging}

An isothermal aging treatment was performed to simulate the thermal stress that materials must deal with under the operating conditions in a CSP system. The expertise of the Abengoa researchers and co-authors suggested the two temperatures that were selected for the aging treatment.

- The first one is $900^{\circ} \mathrm{C}$, to simulate the upper limit working temperature of the system, since the open direct receptor can reach this temperature.

- The second isotherm used to age the samples was $750^{\circ} \mathrm{C}$ in order to cover the operational temperature range in the receiver and inside the heat exchanger.

The isothermal aging treatment was performed inside a furnace under air atmosphere.

Samples were gathered at six aging stages and were evaluated after 24, 72, 168, 312, 405, and 500 hours of aging. Hence, the initial stage under study is the material samples as received, and the final stage is the 500 hours aged samples at $900^{\circ} \mathrm{C}$ and at $750^{\circ} \mathrm{C}$, respectively.

\subsection{Thermal stability and specific heat capacity}

The thermal degradation and stability upon the thermal treatments were evaluated by thermogravimetric analysis (TGA) of the solid particles under study, for the initial stage and the final stage at $900^{\circ} \mathrm{C}$ as the worst scenario. The measurements were conducted between $300^{\circ} \mathrm{C}$ and $900^{\circ} \mathrm{C}$ under $\mathrm{N}_{2}$ atmosphere, with a flow of $80 \mathrm{ml} / \mathrm{min}$, at a heating rate of $10 \mathrm{~K} / \mathrm{min}$, with around $30 \mathrm{mg}$ mass, in a TA Instruments SDT Q600.

The specific heat capacity $(C P)$ is a key property to be considered and measured for thermal energy storage materials and must be maximized [14] to achieve higher heat storage capacity. The $C p$ was analyzed by using a Differential Scanning Calorimeter (DSC). Different methods $[18,19]$ have been proposed to measure the $C p$ : dynamic method, iso-step method and areas method. The method selected in the present study was areas method given its highest precision. This method consists on increasing $1^{\circ} \mathrm{C}$ the material temperature inside the DSC and the area is integrated and related to the heat flow response. This area is compared with the one obtained by an internal standard (in this case sapphire). The full-methodology has been previously described by Ferrer et al. [19]. The analyses were performed under $10 \mathrm{~K} / \mathrm{min}$ heating rate. The amount of sample used was around $15 \mathrm{mg}$ and the sample was located into 40 $\mu \mathrm{L}$ aluminum crucible in a DSC 822e device from Mettler Toledo. The experiment was performed under $50 \mathrm{ml} / \mathrm{min} \mathrm{N}_{2}$ flow. Notice that the equipment precision is $\pm 0.3{ }^{\circ} \mathrm{C}$ for temperature and $\pm 0.1 \mathrm{~kJ} / \mathrm{kg} \cdot \mathrm{K}$ for $C p$ results.

\subsection{Optical properties}

The solar absorptance was measured using a PerkinElmer spectrophotometer Lambda 950 with a $150 \mathrm{~mm}$ integrating sphere. This equipment allows to measure transmittance and reflectivity in the whole solar spectrum within $200 \mathrm{~nm}$ to $2500 \mathrm{~nm}$ wavelength $(\lambda)$ range. Two different lamps depending on the wavelength provide the illumination: a deuterium lamp is used for the ultraviolet region (UV), and a halogen lamp is used for the visible and infrared (IR) region. For study purposes, the reflectivity measurements were conducted from $300 \mathrm{~nm}$ to $2500 \mathrm{~nm}$, in the UV-VisNIR. 
A home-made sample holder was designed to enable the measurements of granulated materials (see Figure 2). The window, made of sapphire crystal, acts as a protector preventing the solid particles from entering the spectrophotometer equipment. The sample holder was filled with solid particles and it was enclosed with polymeric cover foam to slightly press the particles towards the sapphire crystal.
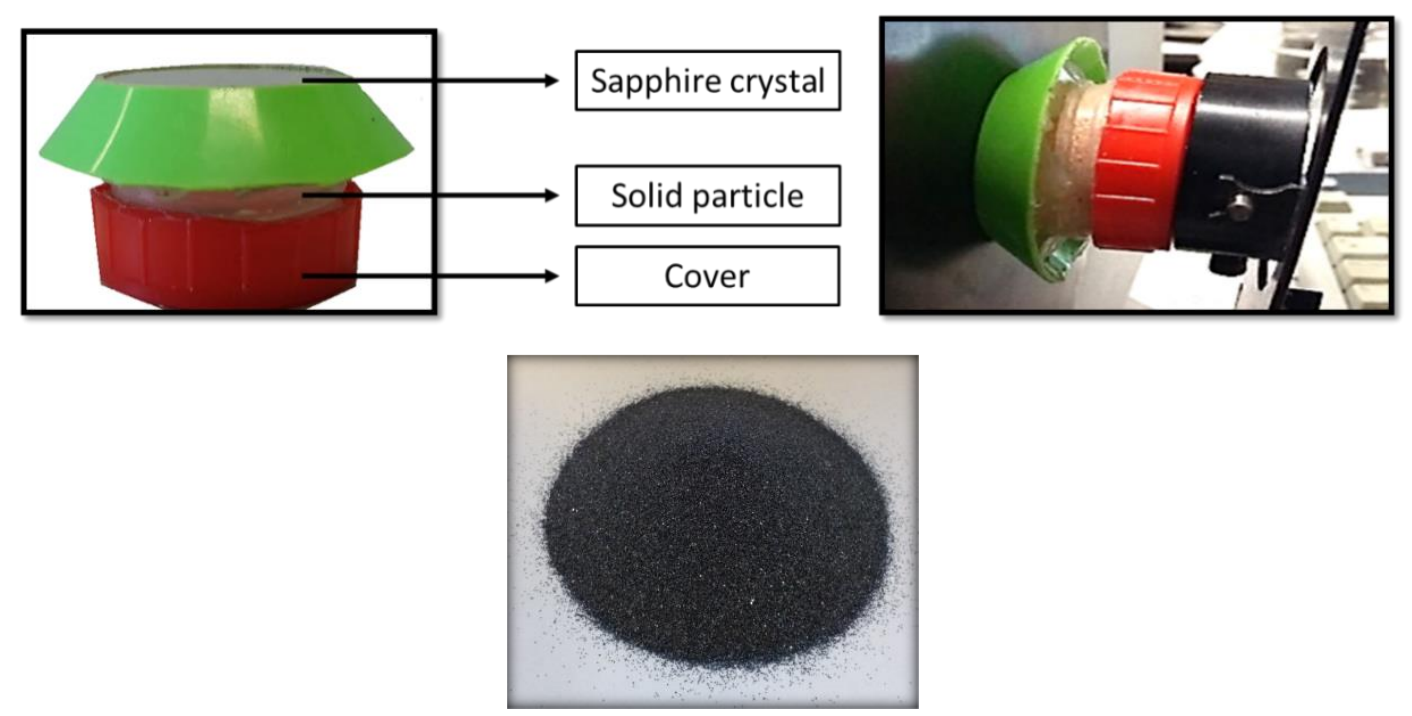

Figure 2. Sample holder and SiC sample.

Given that there is a sapphire crystal between the material and the incident light, it interacts with the light and the solid particles. The crystal reflects a percentage of the incident light, the surface material reflects another percentage, and other minimum fraction is diffusely reflected between the surface and crystal. Therefore, the calibration of the equipment has to be run according to these parameters. To that end, the equipment was calibrated using the sapphire, and the light reflected was considered in the base line.

The methodology used to calculate the solar absorptance has been:

1- Calibration using the sapphire crystal with a white color material for $100 \%$ reflected light to compensate crystal effect.

2- Once the spectrophotometer is calibrated, the reflectivity $(R)$ can be measured in the desired wavelength.

The transmittance $(T)$ is assumed as $0 \%$ when calculating the absorptance $(A)$. Then, $A$ is calculated following Equation 2.

$$
\begin{gathered}
\mathrm{R}_{\lambda}+\mathrm{T}_{\lambda}+\mathrm{A}_{\lambda}=1 \\
\mathrm{R}_{\lambda}+\mathrm{A}_{\lambda}=1
\end{gathered}
$$

Where $\lambda$ indicates the wavelength at which the measure has been performed.

3- Absorptance values are weighted with respect to the values of the solar spectrum AM1.5 (Equation 3) following the standard test conditions defined for solar systems [20]. 


$$
A_{\text {weighted }}=\operatorname{AM} 1.5\left(\mathrm{~W} / \mathrm{m}^{2} \mathrm{~nm}\right) \cdot A_{\text {measured }}
$$

4- Subsequently, a trapezoidal integration [21-23] is performed under the curve to calculate the absolute absorptance of the material as shown in Equation 4.

$$
\sum_{i=1}^{N} \frac{\frac{A_{i}+A_{i+1}}{2}}{N-1}
$$

Where $A_{i}$ is the first low range value, $A_{i+1}$ is the higher range value, and $N$ is the number of values.

Notice that since the absorptance measurements were calibrated with two standards and the noise within the measurement was reduced below $1 \%$ due to the sensor exposure time on each wave length analyzed.

\subsection{Particle color change}

The results from X-Ray diffraction and thermal characterization were analysed to explain the particles colour change after the aging, which could be related to a phase transformation mechanism or a change in oxidation state of the metal ions either accomplished or not by a phase change [13]. X-Ray diffraction was used to determine changes in the crystalline phases; the equipment used was a PANalytical X'Pert PRO MPD $\theta / \theta$ Bragg-Brentano powder diffractometer of $240 \mathrm{~mm}$ of radius. The experiments were performed at room temperature and the samples were prepared by manual pressing some of the received powder material, in rectangular standard sample holders of $20 \mathrm{~mm}$ of length, $15 \mathrm{~mm}$ of width and $1 \mathrm{~mm}$ of height.

\section{Results and discussion}

\subsection{Thermal stability and specific heat capacity}

The thermal degradation test of initial and aged materials at $750^{\circ} \mathrm{C}$ and $900^{\circ} \mathrm{C}$ shows that, after the aging treatment, materials are thermally stable, and TGA results show no mass change with temperature for the three solids. Despite the TGA results for the initial SiC and silica sand samples show no thermal degradation, the result for the iron oxide is different. As it can be seen in Figure 3 a slight mass loss $(1.36 \%)$ is observed when heating the initial $\mathrm{Fe}_{2} \mathrm{O}_{3}$ sample, within the temperature range from $600-800^{\circ} \mathrm{C}$. This mass loss is attributed to the thermal decomposition of the impurity dolomite $\left(\mathrm{MgCO}_{3} \cdot \mathrm{CaCO}_{3}\right)$ to form the corresponding $\mathrm{MgO}$ and $\mathrm{CaO}$ and releasing $\mathrm{CO}_{2}$. Notice that this mass loss is only measured in the initial $\mathrm{Fe}_{2} \mathrm{O}_{3}$ sample. 


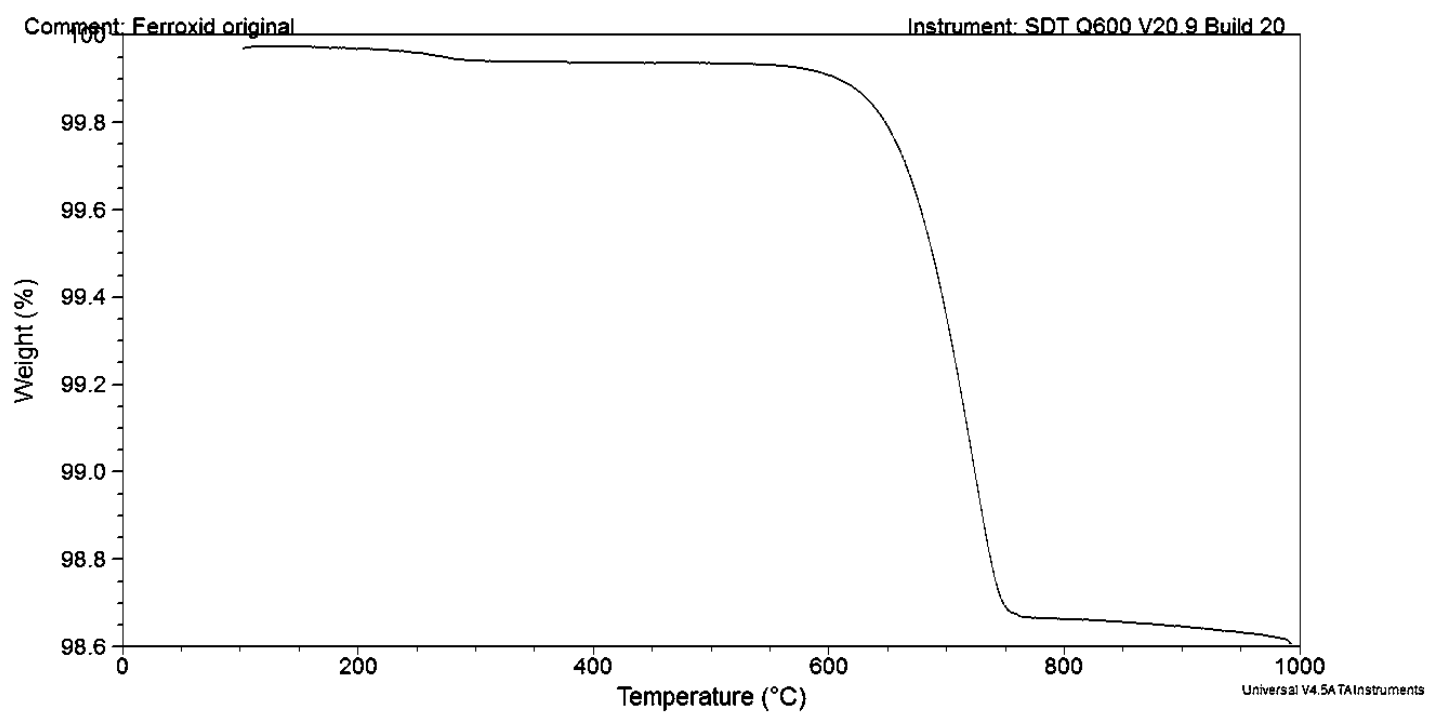

Figure 3. TGA result for initial sample $\mathrm{Fe}_{2} \mathrm{O}_{3}$.

The heat capacity of the solid particles under study was measured at different isotherms using a DSC. The measurements were performed at $100^{\circ} \mathrm{C}$ and $400^{\circ} \mathrm{C}$, according to the technical specifications of the DSC with a \pm 0.1 error.

The results are summarised in Table 2 for initial and aged samples. For the initial materials (as received), the specific heat capacities of silicon carbide and iron oxide are higher than for silica sand. After the aging treatment at $750{ }^{\circ} \mathrm{C}$, black silicon carbide maintains its $C p$ value, while in iron oxide remains the same. Silica sand aging treatment at $750{ }^{\circ} \mathrm{C}$ was excluded, since solar absorptance initial measure was too low. Instead, a complete characterization of iron oxide was carried out. In the case of $900^{\circ} \mathrm{C}$ treatments, black silicon carbide and iron oxide $C p$ is increased while in iron oxide remain the same at $100{ }^{\circ} \mathrm{C}$ and decreases at $400{ }^{\circ} \mathrm{C}$.

The highest $C p$ values are achieved by silicon carbide aged at $750{ }^{\circ} \mathrm{C}$ and $900{ }^{\circ} \mathrm{C}$ when the $C p$ is measured at $400^{\circ} \mathrm{C}$. The obtained values are $1.4 \mathrm{~J} / \mathrm{g} \cdot{ }^{\circ} \mathrm{C}$ and $1.8 \mathrm{~J} / \mathrm{g} \cdot{ }^{\circ} \mathrm{C}$, at $750{ }^{\circ} \mathrm{C}$ and $900{ }^{\circ} \mathrm{C}$, respectively. Regarding silica sand, the measured values are higher when aged at $900^{\circ} \mathrm{C}$ in comparison with initial $C p$ measured, which is consistent with other values reported in the literature due to its differences in composition (impurities) [14,24].

Table 2. Cp results for the studied samples as received and after aging at $750^{\circ} \mathrm{C}$ and $900^{\circ} \mathrm{C}$. Values measured at $100^{\circ} \mathrm{C}$ and $400^{\circ} \mathrm{C}$ by $\mathrm{DSC}$.

\begin{tabular}{|c|c|c|c|c|c|}
\hline Material & \multicolumn{2}{|c|}{$C p$ initial $\left(\mathrm{J} / \mathrm{g} \cdot{ }^{\circ} \mathrm{C}\right)$} & \multirow[t]{2}{*}{$\begin{array}{c}\text { Aging } \\
\text { temperature } \\
\left({ }^{\circ} \mathrm{C}\right)\end{array}$} & \multicolumn{2}{|c|}{$\begin{array}{c}C p \text { after } 500 \mathrm{~h} \text { of aging } \\
\left(\mathrm{J} / \mathrm{g} \cdot{ }^{\circ} \mathrm{C}\right)\end{array}$} \\
\hline T. Sample & $100^{\circ} \mathrm{C}$ & $400^{\circ} \mathrm{C}$ & & $100^{\circ} \mathrm{C}$ & $400^{\circ} \mathrm{C}$ \\
\hline \multirow{2}{*}{$\begin{array}{c}\text { Black silicon } \\
\text { carbide }\end{array}$} & \multirow{2}{*}{$1.3 \pm 0.1$} & \multirow{2}{*}{$1.5 \pm 0.1$} & 900 & $1.6 \pm 0.1$ & $1.8 \pm 0.1$ \\
\hline & & & 750 & $1.3 \pm 0.1$ & $1.4 \pm 0.1$ \\
\hline \multirow[t]{2}{*}{ Silica sand } & \multirow{2}{*}{$0.9 \pm 0.1$} & \multirow{2}{*}{$0.8 \pm 0.1$} & 900 & $1.2 \pm 0.1$ & $1.2 \pm 0.1$ \\
\hline & & & 750 & - & - \\
\hline \multirow[t]{2}{*}{ Iron oxide } & \multirow{2}{*}{$1.2 \pm 0.1$} & \multirow{2}{*}{$1.2 \pm 0.1$} & 900 & $1.2 \pm 0.1$ & $1.0 \pm 0.1$ \\
\hline & & & 750 & $0.9 \pm 0.1$ & $0.7 \pm 0.1$ \\
\hline
\end{tabular}


Overall, black silicon carbide shows the highest $C p$ value while the aged iron oxide reports the lowest values, even lower than the iron oxide without aging treatment.

\subsection{Optical properties}

The absorptance values at different aging stages are shown in Figure 4. A first analysis shows that iron oxide and black silicon carbide are the solid particles that present the highest absorptance over time and temperature.

A deep analysis of the observed differences within the materials studied can be explained as follows:

- Black silicon carbide. Silicon carbide presents the highest absorptance, around $91 \%$ in initial stage, and $96 \%$ fter aging at $900^{\circ} \mathrm{C}$. XRD patterns for $\mathrm{SiC}$ before and after the thermal aging during 5 hours at $900{ }^{\circ} \mathrm{C}$ are compared in Figure $5 a$. There are not significant changes in XRD patterns. Most of the peaks coincide and are assigned to some of the patterns included in the database for SiC. These patterns slightly differ among them because of different stacking sequences. Slight differences may be also attributed to the sample preparation, as by milling the sample a wide particle size distribution is achieved, thus originating preferential orientation of some crystals.

- Iron oxide. The absorptance is slightly enhanced from the initial state to the aging one $\left(500 \mathrm{~h}\right.$ at $\left.900^{\circ} \mathrm{C}\right)$. No substantial changes can be seen in the XRD diffractogram of samples heated at $900^{\circ} \mathrm{C}$ (Figure 5b), despite a low intensity new peak at a position 42.8 degrees. This peak was checked with the different patterns taking into account the possible presence of impurities ( $\mathrm{Ca}$ and $\mathrm{Mg}$ from dolomite and $\mathrm{Ca}$ and $\mathrm{Al}$ from epidote), and it can be assigned to $\mathrm{CaFe}_{3} \mathrm{O}_{5}$. Decomposition of dolomite observed by TGA (Figure 3 ) could favour the formation of this oxide.

- Silica sand. The opposite tendency is followed in this case. The solar absorptance is decreased down to $14 \%$ over the aging time. As reported in literature [25], $\mathrm{SiO}_{2}$ has polymorphic changes with temperature and pressure towards stable and metastable phases. In particular, at $573^{\circ} \mathrm{C} \alpha$-quartz (rhombohedral) changes to $\beta$-quartz (hexagonal). XRD diffractograms for the initial sample and the sample aged at $900^{\circ} \mathrm{C}$ are shown in Figure 5c. It is clear that structural changes took place when thermal aging treatment was applied. While in the original sample peaks are assigned to $\alpha$-quartz as major phase and potassium aluminium silicate as minor phase, the aged sample shows $\beta$-quartz as major phase, but also keatite, $\alpha$-quartz and potassium aluminium silicate as minor phases.

Overall, black silicon carbide and iron oxide are the solid particles that present better results and almost constant absorptance values over time after extreme conditions $\left(900^{\circ} \mathrm{C}\right.$ and $\left.750^{\circ} \mathrm{C}\right)$. 

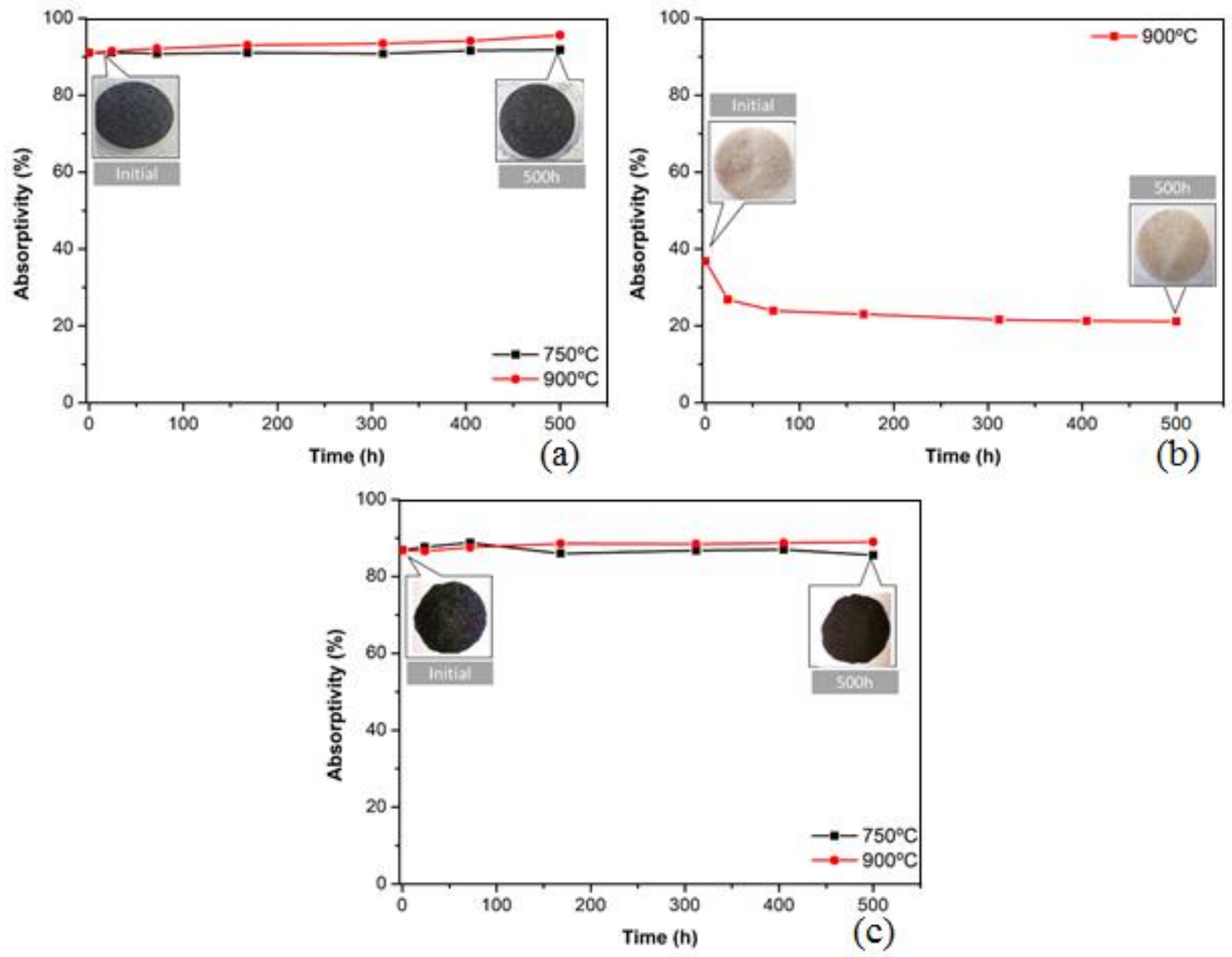

Figure 4. Absorptance for samples aged at $900^{\circ} \mathrm{C}$ (red) and $750^{\circ} \mathrm{C}$ (black): (a) black silicon carbide, (b) silica sand, and (c) iron oxide. 

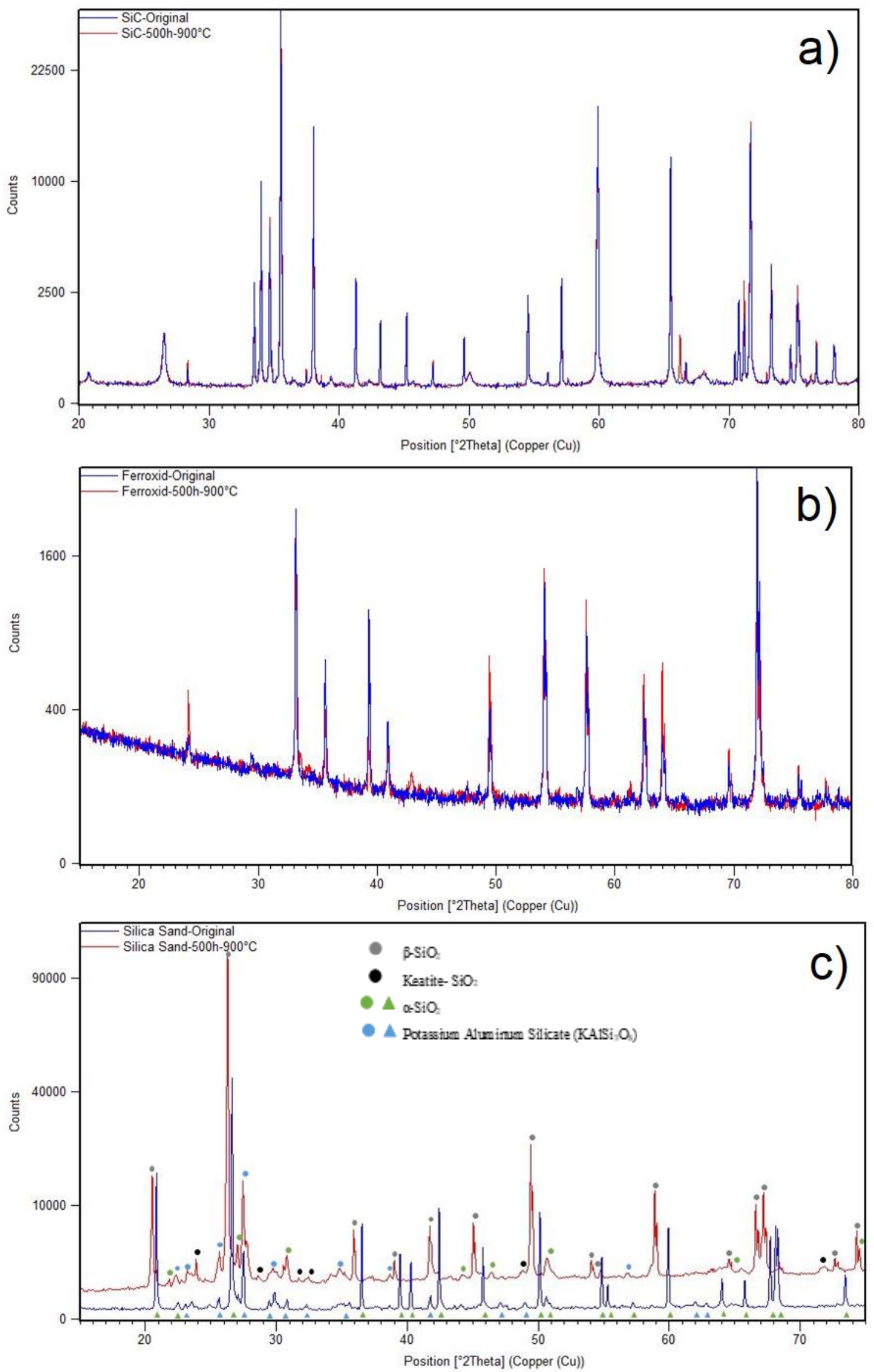

Figure 5. XRD for initial stage, and after aging at $900^{\circ} \mathrm{C}$ for a) black silicon carbide, b) iron oxide, and C) silica sand. 


\section{Conclusions}

The absorptance and thermal stability of three solid particles materials were studied after aging for $500 \mathrm{~h}$ at $750{ }^{\circ} \mathrm{C}$ and $900{ }^{\circ} \mathrm{C}$ to evaluate their possible use as both TES materials and HTF for solar tower with falling down curtain receiver configuration.

The absorptance was observed to increase over the aging stages for black silicon carbide and iron oxide samples. However, for silica sand it decreases with time. The highest absorptance value (95.6\%), within all the materials under study, is shown by black silicon carbide after aging at $900^{\circ} \mathrm{C}$ for $500 \mathrm{~h}$, and this value fits with the one desired for such application. The black silicon carbide also shows the highest specific heat capacity value $\left(1.67 \mathrm{~J} / \mathrm{g}{ }^{\circ} \mathrm{C}\right)$, after aging at $900^{\circ} \mathrm{C}$ for $500 \mathrm{~h}$, measured at $400^{\circ} \mathrm{C}$.

For the reasons previously stated, black silicon carbide stands out as the most appropriate material candidate from the absorptance perspective. It can also be considered thermally stable as no significant changes are expected due to long-termhigh temperature effect.

In summary, this work is focused on the study of some of the most important key properties of materials to ensure a proper heat transfer and thermal stability. The characterization carried out is an approach to the selection and development of solid particle systems for solar power tower plants. Given the different nature of the materials selected (natural and synthetic materials), manufacturing costs should be considered in future analyses. Further thermal, chemical and mechanical characterization is required to validate the material selection procedure.

\section{Acknowledgements}

The work is partially funded by the Spanish government ENE2015-64117-C5-2-R (MINECO/FEDER), and the Catalan Government (2017 SGR118).

The research leading to these results has received funding from the Agency for Business Competitiveness of the Government of Catalonia, and Consejo Nacional de Ciencia y Tecnología CONACYT from México for the doctoral grant 546692.

\section{References}

[1] European Commision, Communication from the Commission to the European Parliament, the Council, the European economic and social Committee and the Committee of the Regions - A policy framework for climate and energy in the period from 2020 to 2030, Eur. Comm. (2014) Brussels.

[2] International Energy Agency, Solar Energy Perspectives, 2011. doi:10.1787/9789264124585-en.

[3] D.Y. Goswami, Principles of Solar Engineering, Third Edition, 2015. doi:10.1017/CBO9781107415324.004.

[4] Z. Ma, G.C. Glatzmaier, M. Mehos, Development of Solid Particle Thermal Energy Storage for Concentrating Solar Power Plants that Use Fluidized Bed Technology, Energy Procedia. 49 (2014) 898-907. doi:10.1016/j.egypro.2014.03.097.

[5] K. Lovegrove, J. Pye, Fundamental principles of concentrating power (CSP) systems, in: Conc. Sol. Power Technol., Elsevier, 2012: pp. 16-67. doi:10.1533/9780857096173.1.16.

[6] W.-D. Steinmann, Thermal energy storage systems for concentrating solar power (CSP) plants, Elsevier, 2012. doi:10.1533/9780857096173.2.362.

[7] G. Flamant, D. Gauthier, H. Benoit, J.-L. Sans, R. Garcia, B. Boissière, R. Ansart, M. Hemati, Dense suspension of solid particles as a new heat transfer fluid for concentrated 
solar thermal plants: On-sun proof of concept, Chem. Eng. Sci. 102 (2013) 567-576. doi:10.1016/j.ces.2013.08.051.

[8] Z. Ma, G. Glatzmaier, M. Mehos, Fluidized Bed Technology for Concentrating Solar Power With Thermal Energy Storage, J. Sol. Energy Eng. 136 (2014) 031014. doi:10.1115/1.4027262.

[9] C.K. Ho, High Temperature Falling Particle Receiver, Sunshot CSP R\&D FOA Ward Recip. (n.d.). http://energy.sandia.gov/wp/wpcontent/gallery/uploads/8_Falling_Particle_Receiver_SunShot_FOA_poster_2012_v3.pd $\mathrm{f}$ (accessed January 10, 2015).

[10] A. Calderón, A. Palacios, C. Barreneche, M. Segarra, C. Prieto, A. Rodriguez-Sanchez, A.I. Fernández, High temperature systems using solid particles as TES and HTF material: A review, Appl. Energy. 213 (2018) 100-111. doi:https://doi.org/10.1016/j.apenergy.2017.12.107.

[11] J.R. Hellmann, V.S. Mcconnell, Characterization of Spherical Ceramic Particles for Solar Thermal Transfer Media: A Market Survey, 1986.

[12] P.. Falcone, J.. Noring, C.. Kackett, Evaluation and application of solid thermal energy carriers in a high temperature solar reciever system., Proc. Intersoc. Energy Convers. Eng. Conf. 3 (1982) 1498-1503. https://www.scopus.com/inward/record.uri?eid=2-s2.00020268353\&partnerID=40\&md5=0fd146c5ba361f5ee212b5971ed336f 8 .

[13] N. Siegel, M. Gross, C. Ho, T. Phan, J. Yuan, Physical Properties of Solid Particle Thermal Energy Storage Media for Concentrating Solar Power Applications, Energy Procedia. 49 (2014) 1015-1023. doi:10.1016/j.egypro.2014.03.109.

[14] T. Baumann, S. Zunft, Properties of granular materials as heat transfer and storage medium in CSP application, Sol. Energy Mater. Sol. Cells. 143 (2015) 38-47. doi:10.1016/j.solmat.2015.06.037.

[15] H. Zhang, J. Degr??ve, J. Baeyens, S.Y. Wu, Powder attrition in gas fluidized beds, Powder Technol. 287 (2016) 1-11. doi:10.1016/j.powtec.2015.08.052.

[16] C. Ho, J. Christian, D. Gill, A. Moya, S. Jeter, S. Abdel-Khalik, D. Sadowski, N. Siegel, H. Al-Ansary, L. Amsbeck, B. Gobereit, R. Buck, Technology Advancements for Next Generation Falling Particle Receivers, Energy Procedia. 49 (2014) 398-407. doi:10.1016/j.egypro.2014.03.043.

[17] C.K. Ho, Technology Pathway - Particle Receivers, in: Sandia National Laboratories, Albuquerque, NM, 2016.

[18] F.G.S.L. Brandao, M. Cramer, Entanglement area law from specific heat capacity, Arxiv. (2014) 5. doi:10.1103/PhysRevB.92.115134.

[19] G. Ferrer, C. Barreneche, A. Solé, I. Martorell, L.F. Cabeza, New proposed methodology for specific heat capacity determination of materials for thermal energy storage (TES) by DSC, J. Energy Storage. 11 (2017) 1-6. doi:10.1016/j.est.2017.02.002.

[20] ASTM, Standard Tables for Reference Solar Spectral Irradiances : Direct Normal and, Astm. 03 (2013) 1-21. doi:10.1520/G0173-03R12.2.

[21] E. Céspedes, M. Wirz, J.A. Sánchez-garcía, L. Alvarez-fraga, R. Escobar-galindo, C. Prieto, Solar Energy Materials \& Solar Cells Novel Mo - Si 3 N 4 based selective coating for high temperature concentrating solar power applications, Sol. Energy Mater. Sol. Cells. 122 (2014) 217-225. doi:10.1016/j.solmat.2013.12.005.

[22] S. Mno, D. Fan, Q. Li, P. Dai, Acta Astronautica Temperature-dependent emissivity property, 121 (2016) 144-152. doi:10.1016/j.actaastro.2016.01.001.

[23] N. Selvakumar, H.C. Barshilia, Solar Energy Materials \& Solar Cells Review of physical vapor deposited ( PVD ) spectrally selective coatings for mid- and high-temperature solar thermal applications, Sol. Energy Mater. Sol. Cells. 98 (2012) 1-23. doi:10.1016/j.solmat.2011.10.028.

[24] M. Diago, A.C. Iniesta, A. Soum-Glaude, N. Calvet, Characterization of desert sand to be used as a high-temperature thermal energy storage medium in particle solar receiver technology, Appl. Energy. 216 (2018) 402-413. doi:10.1016/j.apenergy.2018.02.106.

[25] N. Wilberg, A.F. Holleman, E. Wilberg, Holleman-Wiberg's Inorganic Chemistry, First Edit, Academic Press, New York, 2001. https://www.amazon.com/Holleman-Wibergs- 
Inorganic-Chemistry-Nils-

Wiberg/dp/0123526515?SubscriptionId=AKIAIOBINVZYXZQZ2U3A\&tag=chimbori0 5 -20\&linkCode $=x m 2 \&$ camp $=2025 \&$ creative $=165953 \&$ creative $A S I N=0123526515$. 